\title{
Molecular characterization of Enterobacteriaceae producing $\beta$-lactamase and methicillin-resistant staphylococci isolated from the hospital environment and catheters in two public hospitals in Benin
}

\section{Elodie GBOTCHE}

Universite d'Abomey-Calavi

Victorien Tamègnon DOUGNON ( $\nabla$ victorien.dougnon@gmail.com )

Universite d'Abomey-Calavi https://orcid.org/0000-0001-9047-7299

\section{Yossounon $\mathrm{CHABI}$}

Universite d'Abomey-Calavi Faculte des Sciences de la Sante

Jerrold AGBANKPE

Universite d'Abomey-Calavi

Esther DEGUENON

Universite d'Abomey-Calavi

\section{Paulin SEDAH}

Universite d'Abomey-Calavi

\section{Kafayath FABIYI}

Universite d'Abomey-Calavi

\section{Lamine BABA-MOUSSA}

Universite d'Abomey-Calavi

Clément AGBANGLA

Universite d'Abomey-Calavi

\section{Honoré BANKOLE}

Universite d'Abomey-Calavi

\section{Research article}

Keywords: Antimicrobial resistance, resistance genes, hospital environment, catheters, Benin.

Posted Date: July 17th, 2020

DOI: https://doi.org/10.21203/rs.3.rs-38352/v1

License: (a) (i) This work is licensed under a Creative Commons Attribution 4.0 International License. Read Full License 


\section{Abstract}

Background: Antimicrobial resistance is a real public health problem. All over the world, it has a considerable impact in hospitals. The present study aims to analyze the presence of resistance genes and bacterial ecology in two hospitals in Benin.

Methods: To do this, 146 environmental and catheter samples were collected at the University Hospital Center of Abomey-Calavi / So-Ava and at the Beninese Army Hospital. These samples were inoculated on Mannitol Salt and Eosin Methylene Blue agars. The colonies obtained were identified and their sensitivity to antibiotics was tested, using the usual bacteriological techniques. Four resistance genes encoding the production of extended spectrum beta-lactamases (blaCTX-M1, blaCTX-M2, blaCTX-M9, blaCTX-M15) have been searched in the genome of enterobacteriaceae strains. At the level of staphylococci, the gene coding for methicillin resistance $(m e c A)$ was sought.

Results: At the end of this study, 69 strains of enterobacteria and 60 of staphylococci were identified. A predominance of Staphylococcus aureus (25.6\%) followed by Enterobacter cloacae(21.0\%) and coagulase negative staphylococci (21.0\%) was noted. These bacterial strains showed to be multidrug-resistant, particularly to beta-lactams, fluoroquinolones, aminoglycosides and macrolides. Beta-lactamases were identified in the genome of bacterial strains with a predominance of blaCTX-M15 (42.8\%). The frequency of the mecA gene in staphylococci was $50 \%$.

Conclusions: These results show the magnitude of the antimicrobial resistance situation in hospitals. They can be used to support advocacy for urgent action at the national level, especially with regard to the management and efficient use of antimicrobials in Benin.

\section{Background}

Over the past fifty years, the use of antibiotics has led to many therapeutic advances in infectious diseases. However, the massive and sometimes excessive use of antibiotics at hospital has considerably modified microbial ecology and tends to increase the rate of resistant bacteria $[1,2,3]$. Thus, the emergence and rapid dissemination of antibiotic resistance is a major problem for human health [4]. The adaptive power of bacteria is manifested by their ability to appropriate new properties either by modifying their genome (mutations) or by acquiring genetic information via mobile genetic elements such as plasmids and transposable elements [5, 6, 7]. Most bacterial species are able to integrate different determinants of resistance into their genome. Thus, the dissemination of resistance genes between bacteria has led to the appearance of bacteria resistant to several antibiotics in particular the strains of Staphylococcus aureus resistant to methicillin (MRSA), the enterobacteria producing betaextended spectrum lactamases (ESBL) and vancomycin resistant enterococci (VRE) $[8,9,10]$. Among bacteria resistant to antibiotics, enterobacteria producing broad spectrum $\beta$-lactamase (ESBL) represent a major global threat in hospitals [8]. Often associated with urinary tract infections, they can also cause serious infections associated with the bloodstream [8]. Staphylococcus aureus is the leader in the family of staphylococci because of its involvement in suppurative, localized or severe systemic pathologies in humans [11, 12]. However, other species of staphylococci (coagulase negative staphylococci) can cause a lot of damage to their hosts. This is the case, for example, with Staphylococcus saprophyticus, which is the second bacteria responsible for the infection of the urinary tract after Escherichia coli [9]. 
In February 2017, WHO ranked germs based on antibiotic resistance. According to this classification, Acinetobacter baumannii, Pseudomonas aeruginosa and enterobacteria producing broad spectrum betalactamases represents a critical emergency as they are resistant to a large number of antibiotics. Six other bacteria including Staphylococcus aureus, Helicobacter pylori, salmonella and Neisseria gonorrhoeae represent a high emergency [13]. Finally, for Streptococcus pneumoniae, Haemophilus influenzae and Shigella spp, the urgency is moderate [13]. More than ever, the prescription of antibiotics must take into account not only the desired effect on the infection but also the effects on the bacterial ecology. Indeed, faced with the urgency of finding new therapies, preserving existing antibiotics and above all limiting the progression of resistance in the environment, the mastery and use of antibiotics particularly in hospitals is a necessity [14]. Thus, antibiotic therapy must therefore be justified in order to be prescribed. Preserving the effectiveness of antibiotics requires rapidly and appropriately reducing the use of these molecules but also the knowledge of the genes that can induce resistance [14]. It is in this same context that this study is situated.

\section{Methods}

\section{Sampling}

It consisted of swabbing the inanimate environment of two health structures in South Benin, namely the AbomeyCalavi / So-Ava University and Hospital Center (UHC) and the Beninese Army Hospital (BAH). The swabbed surfaces were, hospital beds, internal and external door latches, benches, bedside tables, mobile phones, gallows, drums, carts, cradle, weighing table, sink, oxygen cylinder, etc. Swabs were taken according to ISO $14698-1$ (ISO $14698-1,2003)$ and then placed in $3 \mathrm{ml}$ of Heart-Brain broth $[15,16]$.

As for the catheter samples, they were taken according to Cleri et al. [17]. After disinfecting the hands and wearing disposable sterile latex gloves, the catheters were removed without antisepsis. Five centimeters from the inner end of the catheter were then cut with sterile scalpel blades and placed in a sterile tube containing 4 ml of Heart-Brain broth.

In total we sampled 146 samples (Table 1). All samples were sent to the laboratory and incubated. After 16 hours of incubation at $37^{\circ} \mathrm{C}$, the broths were inoculated on agar plates for bacteriological analysis.

Table 1

Distribution of the different types and their number according to the hospital center.

\begin{tabular}{|llll|}
\hline \multirow{2}{*}{ Hospital centers } & \multicolumn{2}{l|}{ Number of different types of samples } & Total \\
\cline { 2 - 4 } & Environment & Catheter & \\
\hline UHC & 49 & 24 & 73 \\
\hline BAH & 56 & 17 & 73 \\
\hline Total & 105 & 41 & 146 \\
\hline UHC: Abomey-Calavi / So-Ava University and Hospital Center; BAH: Beninese Army Hospital \\
\hline
\end{tabular}

\section{Isolation And Identification}

With regard to the isolation of the bacterial strains, the 16-hour subcultures (broths) were seeded on the agar plates (Mannitol Salt and Eosin Methylene Blue agars) according to the techniques described by Dougnon et al., 
[18] and Afle et al. [19]. Gram staining was carried out directly on two to three colonies isolated on each agar. Upon observation, the Gram-negative bacillus (GNB) and Gram-positive cocci (GPC) colonies were then selected. After purification, biochemical identification of GNB was carried out by seeding the API 20 E gallery. For the identification of GPC, catalase, coagulase and DNase tests were carried out.

\section{Antibiotic Susceptibility Test}

An overnight bacterial pre-culture of isolates was diluted to obtain a turbidity of $0.5 \mathrm{McFarland}$ (in sterile distilled water). Kirby Bauer techniques were used to perform the susceptibility testing [20]. Antibiotics of different families were chosen for the resistance pattern of the isolates: aztreonam $(30 \mu \mathrm{g})$; erythromycin $(15 \mu \mathrm{g})$; tobramycin $(10 \mu \mathrm{g})$; ceftriaxone $(30 \mu \mathrm{g})$; ciprofloxacin $(5 \mu \mathrm{g})$; ertapenem $(10 \mu \mathrm{g})$; imipenem $(10 \mu \mathrm{g})$; amoxicillin + clavulanic acid $(30 \mu \mathrm{g})$; gentamicin $(10 \mu \mathrm{g})$; kanamycin $(30 \mu \mathrm{g})$; streptomycin $(10 \mu \mathrm{g})$; nalixidic acid $(30 \mu \mathrm{g})$. Escherichia coli ATCC 25922 and Staphylococcus aureus ATCC 25923 was tested for quality assurance.

\section{Molecular Detection Of Resistance Genes}

The DNA of the isolates was extracted according to the instructions of the Zyppy Plasmid Miniprep Kit from Zymo Research. In order to assess and ensure the quality of the plasmid DNA extracts, a verification was carried out by electrophoresis on a $1 \%$ agarose gel and stained with $0.1 \%$ ethidium bromide (BET). Migration was done at $100 \mathrm{~V}$ for 15 min with $1 \mathrm{X}$ concentrated TBE buffer. The extracted DNA was stored at $-20^{\circ} \mathrm{C}$.

In total, five specific primer pairs of resistance genes (mecA, blaCTX-M1, blaCTX-M2, blaCTX-M9, blaCTX-M15) were identified to assess the resistance of the identified strains. These resistance genes were detected by simplex PCR [21, 22]. The PCR was performed at a total volume of $25 \mu$ containing $1.5 \mu$ l of plasmid DNA; $2.5 \mu$ l of each primer (Sens and Reverse); $1 \mu \mathrm{l}$ of dNTP; $2.5 \mu \mathrm{l}$ of PCR buffer (5X); $0.25 \mu$ l of Taq polymerase; $0.5 \mu \mathrm{l}$ of $\mathrm{MgCl} 2 \mathrm{and}$ $14.25 \mu$ of sterile distilled water.

At the end of the reaction, the PCR products were revealed by electrophoresis on a $2 \%$ agarose gel incorporated with $1 \mu \mathrm{l}$ of BET. $5 \mu \mathrm{l}$ of each PCR product was deposited. The migration was done with TBE $1 \mathrm{X}$ buffer for 25 to 35 minutes at $100 \mathrm{~V}$. The bands were viewed under ultraviolet on a trans-illuminator equipped with a camera. $\mathrm{A}$ scoring of the electrophoretic profiles was made by the presence or absence of a band as a function of the size (in base pairs) expected from the sequence. Table 2 shows the primers used. 
Table 2

Sequences of primers

\begin{tabular}{|c|c|c|c|c|}
\hline Genes & Primers & Sequences $\left(5^{\prime}-3^{\prime}\right)$ & Temperature in ${ }^{\circ} \mathrm{C}$ & References \\
\hline \multirow[t]{2}{*}{ blaCTX-M1 } & $\mathrm{F}$ & GGTTAAAAAATCACTGCGTC & \multirow[t]{2}{*}{51} & \multirow[t]{8}{*}{ [22] } \\
\hline & $\mathrm{R}$ & TTGGTGACGATTTTAGCCGC & & \\
\hline \multirow[t]{2}{*}{ blaCTX-M2 } & $\mathrm{F}$ & ATGATGACTCAGAGCATTCG & \multirow[t]{4}{*}{60} & \\
\hline & $\mathrm{R}$ & TGGGTTACGATTTTCGCCGC & & \\
\hline \multirow[t]{2}{*}{ blaCTX-M9 } & $\mathrm{F}$ & ATGGTGACAAAGAGAGTGCA & & \\
\hline & $\mathrm{R}$ & CCCTTCGGCGATGATTCTC & & \\
\hline \multirow[t]{2}{*}{ blaCTX-M15 } & $\mathrm{F}$ & CACACGTGGAATTTAGGGACT & \multirow[t]{2}{*}{51} & \\
\hline & $\mathrm{R}$ & GCCGTCTAAGGCGATAAACA & & \\
\hline \multirow[t]{2}{*}{ mecA } & $\mathrm{F}$ & TCCAGATTACAACTTCACCAGG & \multirow[t]{2}{*}{51} & \multirow[t]{2}{*}{ [21] } \\
\hline & $\mathrm{R}$ & CCACTTCATATCTTGTAACG & & \\
\hline
\end{tabular}

\section{Statistical Data Processing}

The data were analyzed with statistical software R version 3.6.1. The difference was significant when $p<0.05$. The graphPad Prism 7 software was used to produce the graphs.

\section{Results}

\section{Distribution of isolated strains according to the nature of the sample and the place of sampling}

Of the 146 samples analyzed, 129 bacterial strains were isolated with $86 \%(n=111)$ of the strains isolated from environmental samples and $14 \%(n=18)$ isolated from the catheter samples. Bacterial strains isolated from the environment, Enterobacter cloacae leads with $21 \%(\mathrm{n}=27)$, followed by strains of Staphylococcus aureus and Coagulase-negative Staphylococci with $17.8 \%$ respectively $(n=23)$. We also isolated, the strains of Serratia spp. (7.8\%), Flavimonas horyzyhabitans (4.7\%), Enterobacter spp. (3.9\%), Pantoae spp. (3.9\%) and Acinetobacter baumannii (2.3\%). Regarding strains isolated from catheter samples, Staphylococcus aureus is the most isolated with $7.8 \%(n=10)$ followed by $3.1 \%$ coagulase negative staphylococci $(n=4)$. We also isolated the strains of Escherichia coli (1.6\%), Shigella spp (0.8\%) and Klebsiella pneumoniae (0.8\%) (Table 3). This difference in percentage of the different strains isolated between the two types of samples is not statistically significant ( $\mathrm{Q} \otimes$ 0.05).

The results remained the same in each of the two hospitals where the samples were taken. There is a high prevalence of Enterobacter cloacae strains isolated from environmental samples taken both in the Abomey-Calavi / So-Ava University Hospital Center (UHC) and in the Beninese Hospital of Army (BHA), with respectively $12.5 \%$ ( $\mathrm{n}$ = 9) and $31.6 \%(n=18)$, followed by Staphylococcus aureus (29.8\% for BAH and $8.3 \%$ for UHC) and coagulasenegative staphylococci (19.3\% for BAH and 16.7\% for UHC) (Table 3). These percentage differences are not statistically significant $(p \otimes 0.05)$. Our results showed that from a hospital point of view, we note that the prevalence of Staphylococcus aureus strains is higher in BAH (36.8\%) than in UHC (16.7\%). The same is true for 
the prevalence of Enterobacter cloacae strains (31.6\% for BAH and 12.5\% for UHC) and coagulase negative staphylococci strains (22.8\% for BAH and 19.4 for UHC). In addition, an absence of Enterobacter spp, Steptomonas maltophilia, Flavimonas horyzyhabitans, Acintobacter baumannii, Klebsiella oxytoca, Klebsiella terrigena, Chryseomonas luteala, Shigella spp, Pantoae spp and Escherichia coli strains was noted at BAH samples (Fig. 1.). 
Table 3

Distribution of isolated strains according to the nature of sample.

\begin{tabular}{|c|c|c|c|c|c|c|c|c|c|c|c|c|}
\hline \multirow{3}{*}{$\begin{array}{l}\text { Bacterial } \\
\text { strains } \\
\\
\begin{array}{l}\text { Staphylococcus } \\
\text { aureus }\end{array}\end{array}$} & \multicolumn{4}{|c|}{$\mathrm{UHC}(\mathrm{n}=72)$} & \multicolumn{4}{|c|}{ BAH $(n=57)$} & \multicolumn{4}{|c|}{$\begin{array}{l}\text { Total }(\%) \\
n=129\end{array}$} \\
\hline & \multicolumn{2}{|c|}{$\begin{array}{l}\text { Environment } \\
\text { (\%) }\end{array}$} & \multicolumn{2}{|c|}{$\begin{array}{l}\text { Catheter } \\
(\%)\end{array}$} & \multicolumn{2}{|c|}{$\begin{array}{l}\text { Environment } \\
(\%)\end{array}$} & \multicolumn{2}{|c|}{$\begin{array}{l}\text { Catheter } \\
\text { (\%) }\end{array}$} & \multicolumn{2}{|c|}{$\begin{array}{l}\text { Environment } \\
\text { (\%) }\end{array}$} & \multicolumn{2}{|c|}{$\begin{array}{l}\text { Catheter } \\
\text { (\%) }\end{array}$} \\
\hline & 06 & (8.3) & 06 & (8.3) & 17 & $(29.8)$ & 04 & $(7.0)$ & 23 & $(17.8)$ & 10 & $(7.8)$ \\
\hline $\begin{array}{l}\text { Coagulase- } \\
\text { negative } \\
\text { Staphylococci }\end{array}$ & 12 & $(16.7)$ & 02 & $(2.8)$ & 11 & (19.3) & 02 & $(3.5)$ & 23 & $(17.8)$ & 04 & $(3.1)$ \\
\hline $\begin{array}{l}\text { Enterobacter } \\
\text { cloacae }\end{array}$ & 09 & $(12.5)$ & - & - & 18 & $(31.6)$ & - & - & 27 & $(21.0)$ & - & - \\
\hline $\begin{array}{l}\text { Enterobacter } \\
\text { spp }\end{array}$ & 05 & $(6.9)$ & - & - & - & - & - & - & 05 & (3.9) & - & - \\
\hline $\begin{array}{l}\text { Steptomonas } \\
\text { maltophilia }\end{array}$ & 01 & $(1.4)$ & - & - & - & - & - & - & 01 & $(0.8)$ & - & - \\
\hline $\begin{array}{l}\text { Flavimonas } \\
\text { horyzyhabitans }\end{array}$ & 06 & (8.3) & - & - & - & - & - & - & 06 & $(4.7)$ & - & - \\
\hline $\begin{array}{l}\text { Acintobacter } \\
\text { baumannii }\end{array}$ & 03 & $(4.2)$ & - & - & - & - & - & - & 03 & (2.3) & - & - \\
\hline $\begin{array}{l}\text { Klebsiella } \\
\text { pneumoniae }\end{array}$ & 01 & (1.4) & - & - & 01 & $(1.8)$ & 01 & $(1.8)$ & 02 & $(1.6)$ & 01 & $(0.8)$ \\
\hline $\begin{array}{l}\text { Klebsiella } \\
\text { oxytoca }\end{array}$ & 01 & $(1.4)$ & - & - & - & - & - & - & 01 & $(0.8)$ & - & - \\
\hline $\begin{array}{l}\text { Klebsiella } \\
\text { terrigena }\end{array}$ & 01 & $(1.4)$ & - & - & - & - & - & - & 01 & $(0.8)$ & - & - \\
\hline $\begin{array}{l}\text { Chryseomonas } \\
\text { luteala }\end{array}$ & 01 & $(1.4)$ & - & - & - & - & - & - & 01 & $(0.8)$ & - & - \\
\hline Shigella spp & 02 & $(2.8)$ & 01 & $(1.4)$ & - & - & - & - & 02 & $(1.6)$ & 01 & $(0.8)$ \\
\hline Serratia spp & 08 & $(11.1)$ & - & - & 02 & $(3.5)$ & - & - & 10 & $(7.8)$ & - & - \\
\hline Pantoae spp & 05 & $(6.9)$ & - & - & - & - & - & - & 05 & (3.9) & - & - \\
\hline $\begin{array}{l}\text { Rhanella } \\
\text { aquatillis }\end{array}$ & - & - & - & - & 01 & $(1.8)$ & - & - & 01 & $(0.8)$ & - & - \\
\hline Escherichia coli & - & - & 02 & $(2.8)$ & - & - & - & - & - & - & 02 & $(1.6)$ \\
\hline Total & 61 & $(84.7)$ & 11 & (15.3) & 50 & $(87.7)$ & 07 & (12.3) & 111 & $(86.0)$ & 18 & (14.0) \\
\hline
\end{tabular}

UHC: Abomey-Calavi / So-Ava University and Hospital Center; BAH: Beninese Army Hospital; CNS: Coagulasenegative Staphylococci 


\section{Evaluation Of Bacteremia Linked To Catheters (blc)}

Table 4 provides information on the evaluation of infections associated with catheter-related bacteremia type care in the two hospitals sampled. Staphylococcus aureus is the main bacterial species responsible for BLC with respective frequencies of $54.54 \%$ and $54.14 \%$ at the UHC and at the BAH followed incidentally by Shigella spp $(9.09 \%)$.

Table 4

Frequency of strains responsible for catheter-related bacteremia (BLC)

\begin{tabular}{|lllll|}
\hline & UHC & \multicolumn{3}{c|}{ BAH } \\
\cline { 2 - 5 } & Positifs & $\%$ & Positifs & $\%$ \\
\hline Staphylococcus aureus & $6 / 11$ & 54.54 & $4 / 7$ & 54.14 \\
\hline Coagulase-negative Staphylococci & $2 / 11$ & 18.18 & $2 / 7$ & 28.57 \\
\hline Escherichia coli & $2 / 11$ & 18.18 & - & - \\
\hline Klebsiella pneumoniae & - & - & $1 / 7$ & 14.28 \\
\hline Shigella spp & $1 / 11$ & 9.09 & - & - \\
\hline UHC: Abomey-Calavi / So-Ava University and Hospital Center; BAH: Beninese Army Hospital \\
\hline
\end{tabular}

\section{Evaluation of the resistance profile of strains}

At $\mathrm{BAH}$, enterobacteria were more resistant to the aminoglycosides tested, particularly gentamicin (60\%). The fluoroquinolones (ciprofloxacin, nalixidic acid) revealed a resistance of $69 \%$ of the staphylococcal strains (Table 5). High percentages of resistance were identified at the UHC. Beta-lactams (aztreonam, imipenem, ertapenem, ceftriaxone, amoxicillin + clavulanic acid) revealed resistance of $74 \%$ of the strains of enterobacteria. As for staphylococci, macrolides (erythromycin) showed resistance of $85 \%$ (Table 6).

Table 5.

Resistance profile of strains isolated at BAH

\begin{tabular}{cccc}
\hline \multicolumn{2}{c}{ Enterobacteriacea } & \multicolumn{2}{c}{ Staphylococci } \\
\hline Families of Antibiotics & \% Resistance & Families of Antibiotics & \% Resistance \\
\hline B-lactams & 55.6 & Fluoroquinolones & 69.0 \\
Fluoroquinolones & 43.0 & Aminoglycosides & 42.8 \\
Aminoglycosides & 60.0 & Macrolides & 47.0 \\
\hline
\end{tabular}


Table 6.

Resistance profile of strains isolated at UHC

\begin{tabular}{cccc}
\hline \multicolumn{2}{c}{ Entérobactéries } & \multicolumn{2}{c}{ Staphylocoques } \\
\hline Families of Antibiotics & \% Resistance & Families of Antibiotics & \% Resistance \\
\hline B-lactams & 74.0 & Fluoroquinolones & 62.5 \\
Fluoroquinolones & 69.0 & Aminoglycosides & 63.3 \\
Aminoglycosides & 66.0 & Macrolides & 85.0 \\
\hline
\end{tabular}

\section{Molecular Characterization Of Resistance Genes}

The resistance genes sought at the two hospitals concerned were found more in bacterial strains isolated from samples of the inanimate environment than in those of catheters. However, the blaCTX-M1, blaCTX-M15 genes are those with the highest prevalence in enterobacteria, with an average of $35.02 \%$ for the blaCTX-M 1 gene and $42.73 \%$ respectively for the blaCTX-M15 genes Our results showed an absence of the blaCTX-M2 gene in enterobacteriaceae strains isolated from catheter samples but present in those isolated from the environment. Likewise, the blaCTX-M9 gene was not detected in enterobacteriaceae strains isolated from BAH catheter samples. In staphylococci, the average frequency of the mecA gene was $50 \%$ in the strains. There is a higher prevalence of the presence of the mecA gene in Staphylococci isolated from the environment than in those isolated in catheter samples (Table 7).

Table 7

Prevalence of resistance genes in strains isolated according to the type of sample.

\begin{tabular}{|lllll|}
\hline Resistance gènes & BAH & \multicolumn{3}{c|}{ UHC } \\
\cline { 2 - 5 } & Environment (\%) & Catheter (\%) & Environment (\%) & Catheter (\%) \\
\hline blaCTX-M1 & 57.1 & 7.1 & 69.0 & 6.9 \\
\hline blaCTX-M2 & 14.3 & - & 34.5 & - \\
\hline blaCTX-M9 & 28.6 & - & 34.5 & 6.0 \\
\hline blaCTX-M15 & 78.6 & 7.1 & 79.3 & 6.0 \\
\hline mecA & 84.2 & 15.8 & 82.3 & 17.6 \\
\hline UHC: Abomey-Calavi / So-Ava University and Hospital Center; BAH: Beninese Army Hospital \\
\hline
\end{tabular}

\section{Discussion}

Most bacterial strains in hospitals carry resistance genes. The study showed that Staphylococcus aureus was $17.8 \%$ isolated from the inanimate environment. This frequency of isolation of $S$. aureus is due to the opportunistic and ubiquitous nature of the germ [23]. Its ability to survive in the hospital environment allows it to be the source of infections associated with healthcare. We observed a $7.8 \%$ prevalence of contaminated catheter. 
This result is lower than the $14 \%$ found in Morocco by Oubihi [24] and Lemsanni [25]. The most isolated bacterial species from the ends of the catheters in the two hospitals are Staphylococcus aureus (55.6\%), Coagulasenegative Staphylococci (22.2\%), Escherichia coli (11.1\%), and Klebsiella pneumoniae (5,6\%). The occurrence of catheter-related bacteremia remains constant during the hospitalization period. According to Douard [26], it is therefore when the catheter is placed that the bacteria are inserted. A second factor linked to the occurrence of bacteremia is the quality of disinfection [27]. This includes hand hygiene, the quality of the antiseptic used for hand hygiene and disinfection of the operating site [28]. On the other hand, the inanimate environment and the catheters were mostly all infected with similar bacterial species. This may be due to transmission by hand in the absence of hand hygiene before and / or after handling. These results are slightly different from the study by Assogba et al. [29] which showed that after a comparative study of bacteria isolated from staff and from the environment, most of the bacteria isolated from staff were found in the hospital environment.

The sensitivity to antibiotics was tested on all the strains identified. The antimicrobial resistance profile showed the partial resistance of the strains to beta-lactams, aminoglycosides, fluoroquinolones and macrolides. These results are slightly lower than those obtained by Ebongué et al. [30] who reported higher frequencies. Other work has also reported the problem of multidrug resistance in hospitals [31, 32]. Microbial resistance to antibiotics is real in Benin and was reported by Ahoyo et al. [33]. This antimicrobial resistance occurs naturally over time in general following genetic modifications, but the excessive and excessive use of antibiotics accelerates the process [34].

Antibiotic resistance is therefore one of the major medical challenges of the 21st century [35]. The major challenge today is to limit the spread of enterobacteria producing broad-spectrum beta-lactamases (ESBL) in the community and especially in hospitals. Indeed, the production of ESBL is the most widespread resistance mechanism in enterobacteria. The results obtained after the PCR confirmed the presence of the genes sought. The blaCTX-M1 and blaCTX-M15 genes are the most prevalent in enterobacteria, with an average of $35.02 \%$ and $42.73 \%$ respectively. It therefore appears that blaCTX-M15 is the most frequently found ESBL in our study. Several other studies have shown that blaCTX-M15 is the enzyme most commonly found in strains circulating in the hospital environment as well as within the community [36]. The emergence and spread and spread of ESBLs in West African countries are therefore linked to the global expansion of the CTX-M15 type [37]. Among other ESBLs of the CTX-M type, blaCTX-M9 has also been responsible for resistance at lower frequencies of $20.20 \%$ (UHC) and $14.29 \%(\mathrm{BAH})$. As for blaCTX-M2, it was found at $7.13 \%$ and $17.24 \%$ respectively (BAH and UHC). These results are similar to those obtained in Ghana, where half of the enterobacteriaceae (49.4\%) isolated from the various infections 186 diagnosed at Korle-Bu hospital produced ESBL [38]. Also, several isolates have produced more than one ESBL at a time, making therapy in hospitals complex. In addition to the resistance of the isolated enterobacteriaceae strains to beta-lactams, several of them have been resistant to other families of antibiotics (fluoroquinolones, aminoglycosides). This is explained by the fact that all of the ESBL-carrying plasmids also harbor other resistance genes, thus conferring resistance on the vast majority of ESBL enterobacteria to other families of antibiotics, in particular cotrimoxazole, aminoglycosides and fluoroquinolones [39]. The resistance to carbapenems (imipenem, ertapenem) observed is due to the production of ESBL class B which currently represents an emerging concern leading to ineffectiveness of carbapenems [39]. The mecA gene has been found in staphylococcal strains. $52.62 \%$ of Staphylococcus aureus strains carried the mecA gene at BAH compared to $41.17 \%$ at UHC bringing to $46.89 \%$ the average frequency of the strains producing mecA responsible for resistance to methicillin. These results are similar to those of Akerelé et al. [40] in Nigeria where the frequencies of MRSA vary between 20 and 47\% and are much lower than those obtained by Ahoyo et al. [41] in Benin. 
The high proportion of bacteria resistant to antimicrobials observed in our study could be explained by the practice of self-medication in patients and the use of antibiotics of questionable quality during treatment. Dougnon et al. [18] have perceived that the quality of the antibiotic discs used to carry out the antibiograms could be a factor favoring the resistance of bacteria. Therefore, it is important to put an end to self-medication, the use of poorquality antibiotics based on awareness and continuous information of all health actors but also to promote compliance with the measures 'hygiene. In addition, many medical treatments involve presumptive treatment based on data from the literature in developed countries which do not necessarily share the same microbial ecology and can therefore be ill-adapted [42]. It is therefore important to develop antibiotic therapy protocols for the most common diseases in a multidisciplinary framework, taking into account the local reality of antibiotic resistance.

\section{Conclusion}

This study made it possible to characterize the antibiotic resistance genes of bacterial strains isolated in a hospital environment. The presence of the mecA gene reflects the resistance observed within staphylococci, particularly those of methicilin-resistant Staphylococcus aureus (MRSA). The presence of the blaCTX-M1, blaCTXM2, blaCTX-M9 and blaCTX-M15 genes indicates the resistance noted within the strains of enterobacteria. In addition, their multidrug resistance to antibiotics confirms the danger that these strains represent not only for patients but also for healthcare personnel. This poses the problem of non-compliance with hygiene measures in hospitals but also the urgency of judicious and responsible management of antibiotics. The two determinants of the emergence and spread of bacterial resistance to antibiotics are the exposure of the population to antibiotics and by the environment of resistant strains. Knowledge of bacterial ecology and of the genes involved in antimicrobial resistance are important factors in the efficient management of infections, but also a means of helping to reduce the phenomenon of antimicrobial resistance in hospitals. The present study is therefore of paramount importance as the results can be used to support advocacy for urgent action at the national level, especially with regard to the management and efficient use of antimicrobials.

\section{Declarations}

\section{Ethical Statements}

Not applicable

\section{Consent to publish}

The current manuscript contains no individual person's data. Therefore consent to publish is not applicable.

\section{Availability of data and materials}

All data generated or analysed during this study is included in this published article and Additional file.

\section{Competing interests}

The authors declare that they have no competing interests

\section{Funding}


No external funding was obtained to carry out this study. It was carried out with own funding from the authors and co-authors.

\section{Authors' contributions}

EG, VD, YC, LB-M, BK and CG wrote the protocol and validated it. JA and ED reviewed the protocol. JA, ED and VD supervised the microbiological analyses which were performed by KF and EG. PS, EG performed the molecular analysis.

\section{Acknowledgements}

All the authors are grateful to Kaisa HAUKKA, University of Helsinki (Finland) for her permanent support about fighting antimicrobial resistance in Africa.

\section{References}

1. World Health Organization. Antimicrobial resistance global report on surveillance. World Health Organization; 2014. 256p.

2. Stewardson AJ, Allignol A, Beyersmann J, Graves N, Schumacher M, Meyer R, et al. The health and economic burden of bloodstream infections caused by antimicrobial-susceptible and non-susceptible Enterobacteriaceae and Staphylococcus aureus in European hospitals, 2010 and 2011: a multicentre retrospective cohort study. Euro surveillance : bulletin Europeen sur les maladies transmissibles = European communicable disease bulletin. 2016 ; 21(33). https://doi.org/10.2807/1560-7917.ES.2016.21.33.

3. Koudokpon H, Dougnon V, Hadjadj L, Kissira I, Fanou B, Loko F, et al. First Sequence Analysis of Genes Mediating Extended-Spectrum Beta-Lactamase (ESBL) bla-TEM, SHV-and CTX-M Production in Isolates of Enterobacteriaceae in Southern Benin. Int J Infect. 2018;5(4): e83194.

4. Blair JM, Webber MA, Baylay AJ, Ogbolu DO, Piddock LJ. Molecular mechanisms of antibiotic resistance. Nat. Rev. Microbiol. 2015, 13, 42-51.

5. Xia Y, Liang Z, Su X, and Xiong Y. Characterization of Carbapenemase Genes in Enterobacteriaceae Species Exhibiting Decreased Susceptibility to Carbapenems in a University Hospital in Chongqing, China. Ann Lab Med. 2012; 32:270-275 http://dx.doi.org/10.3343/alm.2012.32.4.270

6. Wang J, Stephan R, Zurfluh K, Hächler H, Fanning S. Characterization of the genetic environment of bla ESBL genes, integrons and toxinantitoxin systems identified on large transferrable plasmids in multi-drug resistant Escherichia coli. Front Microbiol. 2014; 5:716.

7. Xu H, Huo C, Sun Y, Zhou Y, Xiong Y, Zhao Z, et al. emergence and molecular characterization of multidrugresistant Klebsiella pneumoniae isolates harboring blacTX-M-15 extended-spectrum $\beta$-lactamases causing ventilator-associated pneumonia in china. Infection and Drug Resistance, 2019:12.

8. Naas T, Cuzon G, Robinson AL, Andrianirina Z, Imbert P, Ratsima E, Ranosiarisoa ZN, et al. Neonatal infections with multidrugresistant ESBL-producing cloacae and K. pneumoniae in Neonatal Units of two different Hospitals in Antananarivo, Madagascar. BMC Infectious Diseases, 2016, 16:275.

9. Koudokpon H, Dougnon TV, Kissira SI, Aniambossou A, Fanou BA, Loko F, Bankole H, et al. MethicillinResistance of Staphylococcus Species in Southern Benin: Resistance Gene, Virulence Factor Associated and Staphylococcal Chromosomal Cassette Distribution. International Journal of Microbiology Research, 2017, 9(12): 976-980. 
10. Hagel S, Makarewicz O, Hartung A, Weiß D, Stein C, Brandt C, et al. ESBL colonizationand acquisition in a hospital population:The molecular epidemiology and transmission of resistance genes. PLoSONE, 2019, 14(1): e0208505.https://doi.org/10.1371/journal. pone.0208505

11. Boukhatem N, Ferhat M, Hadj Mohamed R and Lalaoui N. Prevalence and antibiotic resistance of Staphylococci isolated from Kolea Hospital (Algeria). J Fundam Appl Sci., 2015, 7(2), 260-270.

12. Joshi PR, Acharya M, Aryal R, Thapa K, Kakshapati T, Seng R, Singh A, Sitthisak S. Emergence of staphylococcal cassette chromosome mec type I with high-level mupirocin resistance among methicillinresistant Staphylococcus aureus. Asian Pac J Trop Biomed. 2017;7:193-97.

13. World Health Organization (WHO). Why a Global Challenge on Nosocomial Infections, 2017. http://www.who.int/gpsc/back ground / en /. accessed October 24, 2019.

14. Mangin L. Antibiotics and resistance: survey on the knowledge and behavior of the general public. Pharmaceutical sciences. 2016, Hal-01734015.

15. Lemmen SW, Häfner H, Zolldann D, Amedick G, Lutticken R. Comparison of two sampling methods for the detection of GrampositiveandGram-negativebacteriaintheenvironment: moistened swabs versus Rodac plates. Int J Hyg Environ Health. 2001;203: 245-8. https://doi.org/10.1078/S1438-4639(04)70035-8.

16. Cavallo J, Antoniotti G, Baffoy N, Guignement-Coudrais S, Hajjar J, Horn C, et al. Surveillance microbiologique de l'environnement dans les établissements de santé. France ; 2002.https://bdsp-ehesp. inist.fr/vibad/controllers/getNoticePDF.php?path=Ministere/Dgs/ Publications/2002/recofin.pdf. Accessed 2 Sep 2019.

17. Cleri DJ, Corrado ML, Seligman SJ. Quantitative culture of intravenous catheters and other intravascular inserts. J Infect Dis. 1980; 141:781-6. https://doi.org/10.1093/infdis/141.6.781.

18. Dougnon, T.V., Johnson, R.C., Bankolé, H.S., Koudjalé B, Hounmanou, G., Baba-Moussa, L., Boko, M. Evaluation of the performance of three brands of antibiotic discs sold in Benin. Health Sci. Dis, 2016, 17 (4) : 71-78.

19. Afle FCD, Agbankpe AJ, Johnson RC, Houngbegnon O, Houssou SC, and Bankole HS. Healthcare-associated infections: bacteriological characterization of the hospital surfaces in the University Hospital of AbomeyCalavi/so-ava in South Benin (West Africa). BMC Infectious Diseases. 2019, 19:28.

20. CA SFM. Recommandations 2019 V.2.0 du Comité de l'antibiogramme de la Sociét é Française de Microbiologie. 1st edition.2019. sfm-microbiologie.org. Accessed 19 Jun 2019.

21. Yu Y, Ji S, Chen Y, Zhou W, Wei Z, Li L, Ma Y. Resistance of strains producing extended-spectrum betalactamases and genotype distribution in China. The Journal of infection, 2007, 54:53-57.

22. Bittar F, Ouchenane Z, Smati F, Raoult D, Rolain J-M. MALDI-TOF-MS for rapid detection of staphylococcal Panton-Valentine leukocidin. International Journal of Antimicrobial Agents, 2009 ; 34467-470

23. Nauciel C, Vilde JL. Bactériologie médicale. In Editions Masson. 2nd edition. Paris, 2009, 49 - 58.

24. Oubihi B. Epidémiologie des infections nosocomiales en milieu de réanimation. Université CADI AYYAD; 2015. http://wd.fmpm.uca.ma/ biblio/theses/annee-htm/FT/2015/these79-15.pdf. Accessed19Jun2019

25. Lemsanni M. Les infections nosocomiales en réanimation pédiatrique. Université CADI AYYAD; 2016. http://wd.fmpm. uca.ma/biblio/theses/annee-htm/FT/2016/these53-16.pdf. Accessed 19 Jun 2019.

26. Douard MC, Clementi E, Arlet G, Marie O, Jacob L, Schremmer B, et al. Negative catheter-tip culture and diagnosis of catheter-related bacteremia. Nutrition. 10:397-404 http://www.ncbi.nlm.nih.gov/ pubmed/7819651. Accessed 21 Jun 2019. 
27. Dougnon V, Koudokpon H, Hounmanou YM, et al. High Prevalence of Multidrug-Resistant Bacteria in the Centre Hospitalier et Universitaire de la Mère et de l'Enfant Lagune (CHU-MEL) Reveals Implications of Poor Hygiene Practices in Healthcare. SN Compr. Clin. Med. 1, 2019, 1029-1037. https://doi.org/10.1007/s42399019-00149-3

28. SF2H, HAS. Avril 2Pose et entretien des cathéters veineux périphériques : Série de critères de qualité pour l'évaluation et I 'amélioration des pratiques professionnelles007. France;

2007https://www.hassante.fr/portail/upload/docs/application/pdf/201303/catheter_veineux_peripheriques__criteres_de_qualite.pdf. Accessed 19 Jun 2019.

29. Tajeddin E, Rashidana M, Razaghi M, Javadi SS, Sherafat SJ, et al. The role of the intensive care unit environment and health-care workers in the transmission of bacteria associated with hospital acquired infections. J Infect Public Health (2015), http://dx.doi.org/10.1016/j.jiph.2015.05.010

30. Ebongue C, Dongmo Tsiazok M, N'da Mefo'o P, Ngaba GP, Béyiha G, Adiogo D. (2013). Evolution of antibiotic resistance in enterobacteriaceae isolated at the General Hospital of Douala from 2005 to 2012. Pan Afr Med J. $2015 ; 20: 227$.

31. Vodovar D, Marchade G, Raskine L, Malissin I, Mégarbane B. Enterobacteriaceae producing expanded betalactamases: epidemiology, risk factors and preventive measures. Internal Medicine Journal, 2013 ; 34 (11) :687-693.

32. De Angelis G, Restuccia G, Venturiello S, Cauda R, Malhotra-Kumar S, et al. Nosocomial acquisition of methicillin-resistant Staphyloccocus aureus (MRSA) and extendedspectrum beta-lactamase (ESBL) Enterobacteriaceae in hospitalised patients: a prospective multicenter study. BMC Infectious Diseases 2012, $12: 74$

33. Ahoyo AT, Baba-Moussa L, Anago AE, Avogbe P, Missihoun TD, Loko F, et al. Incidence of infections dues to Escherichia coli strains producing extended spectrum betalactamase, in the Zou/Collines Hospital Centre (CHDZ/C) in Benin. Med Mal Infect. 2007; 37(11):746-52.French. doi: 10.1016/j.medmal.2007.03.004.

34. World Health Organization (WHO) 2016. Antimicrobial resistance. http: // www. who.int/mediacentre/factsheets/fs194/en/. Accessed August 29, 2017.

35. A WHO multi-country survey reveals widespread misunderstanding of public opinion regarding antibiotic resistance [Internet]. WHO. [cited 2016 Jul 11]. Available from:

http://www.who.int/mediacentre/news/releases/2015/antibioticresistance/ en /

36. Ogbolu DO, Alli OAT, Webber MA, Oluremi SA, and Oloyede CTX-M-15 is Established in Most MultidrugResistant Uropathogenic Enterobacteriaceae and Pseudomonaceae from Hospitals in Nigeria. European Journal of Microbiology and Immunology 8(2018)1, pp. 20-24

37. Doi Y, lovleva A, and Bonomo The ecology of extended-spectrum b-lactamases (ESBLs) in the developed world. Journal of Travel Medicine, 2017, Vol. 24, Suppl 1.

38. Feglo P, Adu-Sarkodie Y, Ayisi L, Jain R, Spurbeck RR, Springman AC, et al. Emergence of a Novel ExtendedSpectrum--Lactamase (ESBL)- Producing, Fluoroquinolone-Resistant Clone of Extraintestinal Pathogenic Escherichia coli in Kumasi, Ghana. Journal of Clinical Microbiology, 2013, 51(2) : 728 -730

39. Reuland EA, Al Naiemi N, Kaiser AM, Heck M, Kluytmans JA, Savelkoul PH, et al. Prevalence and risk factors for carriage of ESBL-producing Enterobacteriaceae in Amsterdam. The Journal of antimicrobial chemotherapy. 2016; 71(4):1076-82. https://doi.org/10.1093/jac/dkv441. 
40. Akerele JO, Obasuyi O, Onyeagwara N, Ottih I. Methicillin-Resistant Staphylococcus 598 aureus (MRSA):An Emerging Phenomenon among non-Hospitalized Otorhinolaryngological Patients in Benin City, Nigeria. West Afr J Med. 2014 Oct-Dec;33(4):276-9.

41. Anago E, Ayi-Fanou L, Akpovi CD, Hounkpe WB, Agassounon-Djikpo Tchibozo M, Bankole HS, et al. Antibiotic resistance and genotype of beta-lactamase producing Escherichia coli in nosocomial infections in Cotonou, Benin. Ann Clin Microbiol Antimicrob. 2015; 14:5. doi: 10.1186/s12941-014-0061-1.

42. Ouedraogo, A., Pierre Jean, H., Banuls, A., Ouédraogo, R. and Godreuil, S. Emergence and spread of antibiotic resistance in West Africa: enabling factors and assessment of the threat emergence and spread of antibiotic resistance in West Africa: Contributing factors and threat assessment. Med. Sante Trop., 2017, 27(2): 147154.

\section{Figures}

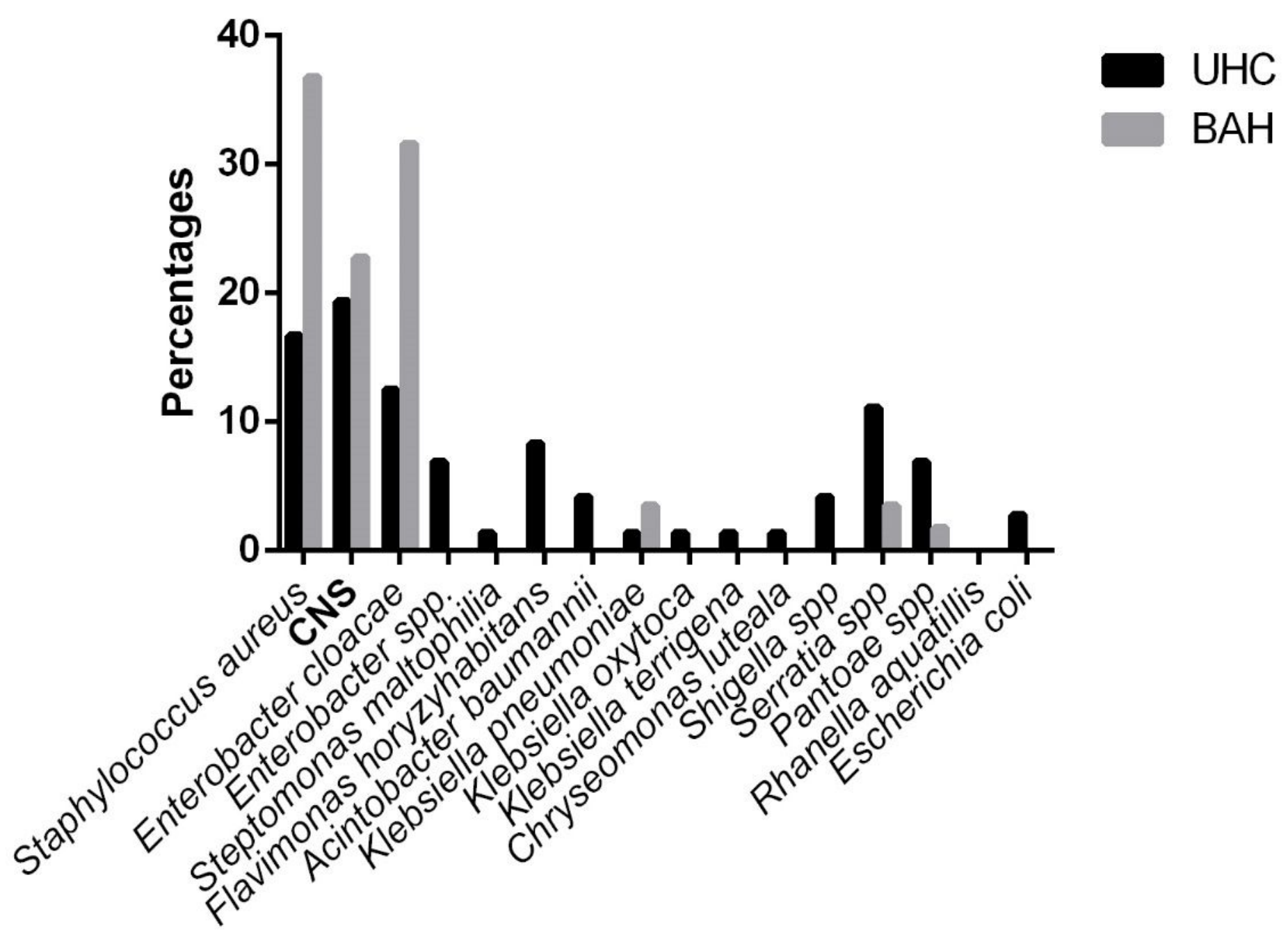

Figure 1

Distribution of isolated strains according to the sampling location. UHC: Abomey-Calavi / So-Ava University and Hospital Center; BAH: Beninese Army Hospital; CNS: Coagulase-negative Staphylococci 